\title{
Hyper abundant mesopredators and bird extinction in an Atlantic forest island
}

\author{
Mauro Galetti 1; Ricardo S. Bovendorp 1; Rodrigo F. Fadini 1, 2; Carlos O. A. Gussoni 1; \\ Marcos Rodrigues ${ }^{3}$; Ariane D. Alvarez ${ }^{\text {; }}$ Paulo R. Guimarães Jr ${ }^{4}$ \& Kaiser Alves ${ }^{1}$
}

\author{
${ }^{1}$ Laboratório de Biologia da Conservação, Departamento de Ecologia, Universidade Estadual Paulista. Caixa Postal 199, Rio \\ Claro 13506-900, São Paulo, Brasil. Email: mgaletti@rc.unesp.br \\ ${ }^{2}$ Coordenação de Pesquisas em Ecologia, Instituto Nacional de Pesquisas da Amazônia. 69011 -970 Manaus, Amazonas, \\ Brasil. \\ ${ }^{3}$ Departamento de Zoologia, Universidade Federal de Minas Gerais. Caixa Postal 486, 31270-901 Belo Horizonte, Minas \\ Gerais, Brasil. \\ ${ }^{4}$ Department of Ecology and Evolutionary Biology, University of California. Santa Cruz, 95060, CA, USA.
}

\begin{abstract}
Islands can serve as model systems for understanding how biological invasions affect native species. Here we examine the negative effects of mesopredator mammals on bird richness at Anchieta Island, an 826 ha offshore island in the coast of Brazil. Anchieta Island has the highest density of mammals of the entire Atlantic forest, especially nest predators such as marmosets and coatis, introduced more than 20 years ago. This indiscriminate introduction of mammals may have affected directly the bird community, nowadays represented by 100 species comprised mainly by watercrossing birds, being 73 forest-dwelling species. A small component of these remnant bird species nests in tree holes and on the forest floor, null model analysis suggest that birds within these two nest types are under-represented on Anchieta Island. All guilds were affected negatively, but "opportunist insectivorous/omnivorous". Experiments using artificial nests showed a predation of $73 \%$ of nests on the floor while only $26 \%$ on the mainland. Camera traps recorded predation by coatis, agoutis, and opossums. The restoration of the bird community on this island is highly constrained by the high density of hyper abundant nest predators.
\end{abstract}

KEY WORDS. Callithrix; exotic species; line transect; mesopredator release; null models.

The introduction of vertebrate alien species is one of the main threats to the conservation of native species, especially in island ecosystems (e.g. Biвby 1995, Clout 2002). Mammal populations when introduced on islands usually became hyper abundant due to the absence of their predators, competitors and parasites (Emmel 1976, Vitouser et al. 1995, Terborgh et al. 2001), and they represent one of the most important taxa concerning biological invasions on such habitats. In fact, a small number of mammal species is responsible for most of the damage to invaded insular ecosystems, such as rats, cats, goats, rabbits, pigs and a few others (COURChamp et al. 2003, Cuthbert \& HiLTon 2004). Islands with more exotic mammal predator species have lost a greater proportion of their avifauna since European colonization (BLACKBURN et al. 2004). Cats and rats have a strong impact on nest and bird predation (RoBinET et al. 1998, Thibault et al. 2002, Nogales et al. 2004).

The Atlantic Forest has one of the highest rate of bird endemism on the planet (Wege \& Long 1995) comprising an avifauna of 682 species, including 199 endemics and 144 threatened species, most due to habitat loss (Sтотz et al. 1996). Islands are the most disturbed components of the entire Atlantic forest ecosystem because they have long history of human occupation and because they are more susceptible to human impact
(Olmos 1996, NaKa et al. 2002). One of these islands is Anchieta Island, in southeast Brazil. In 1983, the São Paulo Zoo introduced in this island 100 mammals from 15 species which originally occurred in the mainland of the Atlantic forest or in Brazilian savannas (Cerrado) such as agoutis, coatis, and marmosets (Bovendorp \& GaLETTI 2007). After 24 years, some mammal species increase 140 times, many of which are nest predators (Bovendorp \& Galetti 2007, Alvarez et al. 2008, Bovendorp et al. 2008). Today, Anchieta Island represents an excellent opportunity to study the impact of introduced mammals on avian extinction at the Atlantic forest.

In this paper we examine the bird diversity at Anchieta Island and test if the absence of some species is due to high predation risk on certain nesting types. We hypothesized that in an island characterized by a hyper abundance of mesopredators some bird nesting types would be more sensitive to predation and the loss of bird species does not follow a random process.

\section{MATERIAL AND METHODS}

The Anchieta Island has 826 ha and is located in the north of São Paulo state, 400 m offshore from Ubatuba, São Paulo state, south-east Brazil $\left(45^{\circ} 02^{\prime} \mathrm{W}, 23^{\circ} 27^{\prime} \mathrm{S}\right.$, Fig. 1). On the mainland, 


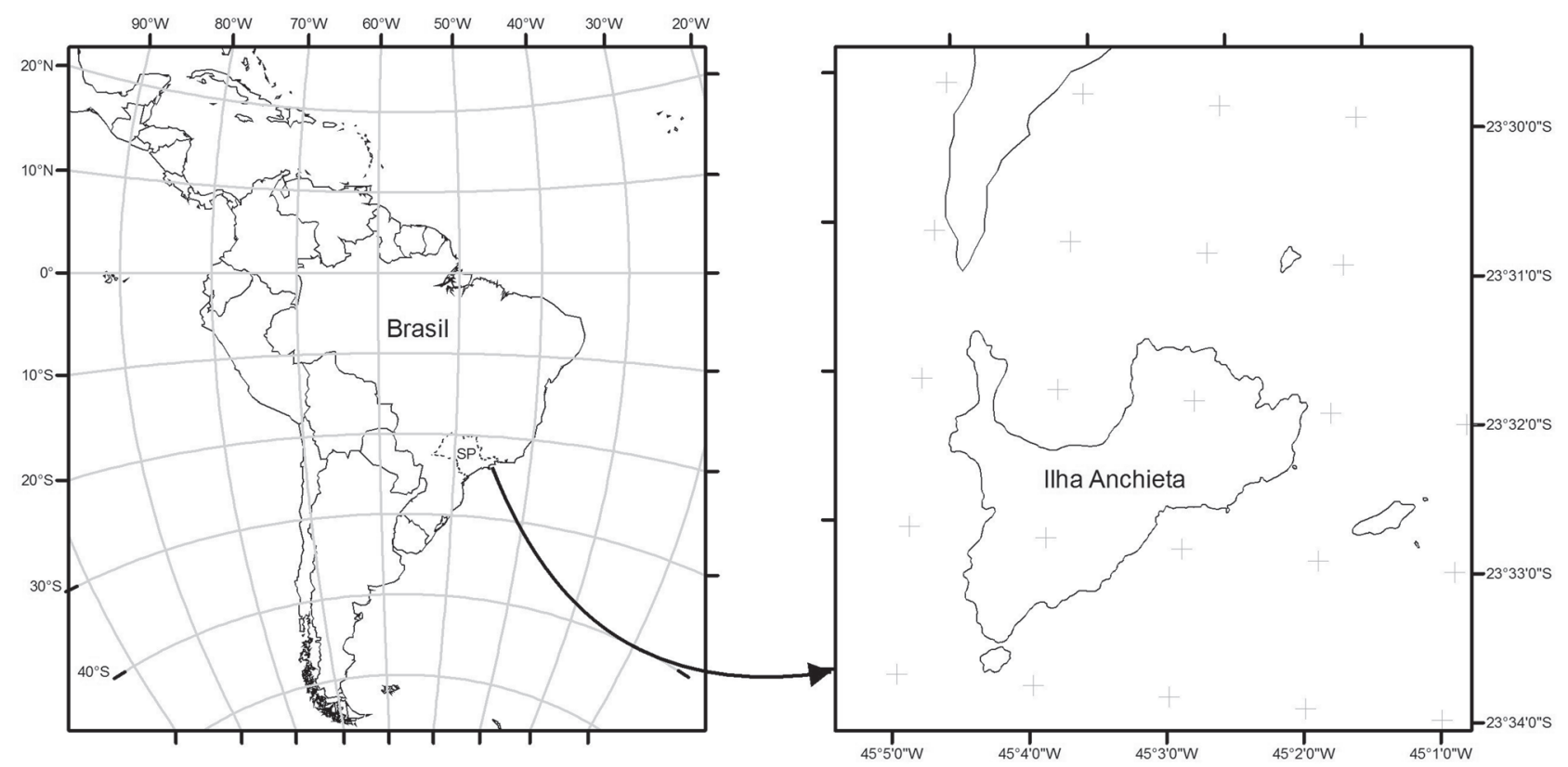

Figure 1. Location of Anchieta Island in the coast of Brazil (based in M. Fleury, unpubl. data).

the Atlantic coastal forest holds one of the highest levels of terrestrial biodiversity on Earth (MYers et al. 2000). The Serra do Mar, to which Anchieta Island is geologically related, is one of the key centers of species endemism (Silva et al. 2004). The island is composed of two hills of up to $330 \mathrm{~m}$ above sea level. Pigs, dogs, cats, and the domestic fowl were brought to the island in order to sustain its human community in the beginning of the last century, especially during the years when a prison was active (1904-1955) (GUILLAumon et al. 1989). The island was transformed in a state park in 1977 and nowadays about 90,000 tourists visit the island per year, especially in the summer, imposing a considerable impact on the island's biodiversity (M. Robim, Instituto Florestal, pers. com).

\section{Bird survey}

We sampled the bird community at Anchieta Island during 23 months (from July 2003 to June 2004 and from December 2005 to January 2007, excluding March and May 2006), totalizing more than 678 hours of observations along the trails, including point counts censuses (FADINI et al. 2009) and 380 hours of mist netting. All birds observed on the island were grouped into categories according to (1) habitat (forest, forest edge or open areas); (2) occurrence status (resident or non-resident); (3) relative abundance (common, rare or vagrant); (4) gap crossing ability (water-crossing and no water crossing) and (5) nesting characteristics. Each bird species was assigned a nest category as follows: aerial-opened, aerial-closed, cavity, groundopened, ground-closed; nest parasite (see Sieving 1992). Nest characteristics were obtained from literature (SICK 1997) and our previous experience. We divided the bird community into twelve feeding guilds, based on Aleixo \& Vielliard (1995), and Anjos \& Boçon (1999).

\section{Statistical Analysis}

We investigated if guild and nest category affect the extinction of birds at Anchieta Island using a null model approach (Gotelli \& Graves 1996). The idea underlying our null model is that bird assemblage of Anchieta Island is essentially a random sample of bird species from the mainland (Caraguatatuba). Indeed, more than $89 \%$ of bird species of Anchieta Island also occur on the mainland and the seven species that occur solely at Anchieta were discarded from null model analyses. Sea birds were not included in our comparisons. If extinction is not related to biological attributes such as nesting habitats and guilds, we expected that the loss of species due to smaller size of the island and/or effects of introduced species would be essentially a random process, that is, all species have the same extinction risk. We simulated random extinctions on the mainland assembly until the number of bird species reaches the same of Anchieta Island. Random extinctions are simulated as follows: we randomly sorted the number of species on Anchieta ( $\mathrm{n}=$ 73) from the pool of Caraguatatuba species $(n=199)$. We repeat this process 1,000 times, recording the number of sorted species in each guild or nest category. Our statistic (p) is the probability that a random replicate has a number of species equal to or more extreme than the observed value (MANLY 1997).

We estimated the number of forest-dwelling bird species that would occur on an inshore island, comparing a dataset of 17 bird lists from land-bridge islands in the Atlantic forest in southeast Brazil. All of these islands were connected to the 
mainland in the Pleistocene and are close to the mainland. We plotted the log of island area vs. the number of forest-dwelling species. The functional form of the relationship followed a power-law and we fitted the distribution using a least-square log-log regression. We therefore predicted the number of forest-dwelling species at Anchieta Island. This regression curve is, however, an underestimation of the probably bird diversity because all islands had recently local extinctions due to human disturbance.

\section{Nest predation experiments}

To evaluate the impact of mesopredators on bird reproduction, we performed an experiment using artificial nests with quail eggs (see Alvarez \& Galetti 2007). Thirty nests on the ground and on the understory vegetation ( 1.3 $\mathrm{m}$ of height) were placed at Anchieta Island and in the mainland (Caraguatatuba). Each nest was composed of two quail eggs (Coturnix coturnix, Linnaeus, 1758 , Phasianidae, $2.5-3 \mathrm{~cm}$ of length). Quail eggs underestimate the overall nest predation, because some mesopredators are not able to break them (Alvarez \& GaletTI 2007). However, due to logistic limitations we decide to use quail eggs instead of canary or plasticine eggs.

The nests on the ground were made using the available botanical matter (MAIER \& DeGraAf 2000), while the understory nests (10 cm of diameter, $3.5 \mathrm{~cm}$ of height) were camouflaged with litter. Nests were placed at intervals of $25 \mathrm{~m}$ along trails. After seven days, the number of eggs preyed upon was recorded. We assumed that either broken or missing eggs were preyed on by vertebrates. Rubber boots and gloves were used during the experiment to minimize human scent and, consequently, reduce experimental bias (Burke et al. 2004). In order to identify the potential nest predators we used two camera traps during 311 hours in nests on the ground and 288 at $1.3 \mathrm{~m}$ height at Anchieta Island. At the mainland we left the cameras for less time (60 hours for ground nests) and 36 hours (for aerial nests).

\section{RESULTS}

\section{Bird species richness and guild losses}

We recorded 100 bird species at Anchieta Island, and 73 forest-dwelling species (Appendix I). We compiled information of 15 land-bridge islands in the coast of Brazil (Tab. I) and plotted a species-area curve to determine the number of species predicted by the size of Anchieta (Fig. 2). We found a strong correlation between island size and number of forest-dwelling bird species $\left(r^{2}=0.75, p<0.0001\right)$ (Fig. 2). Therefore, the number of species found in Anchieta Island is predicted by the species-area relationship (Fig. 2).

Foraging guilds were severely impoverished at Anchieta Island. Nevertheless, the current bird composition at Anchieta Island is almost entirely reproduced by our null model that assumes random extinctions (Tab. II). The proportion of birds in the guild "opportunist omnivorous/insectivorous" was the only one that differed in relation to the mainland, increasing

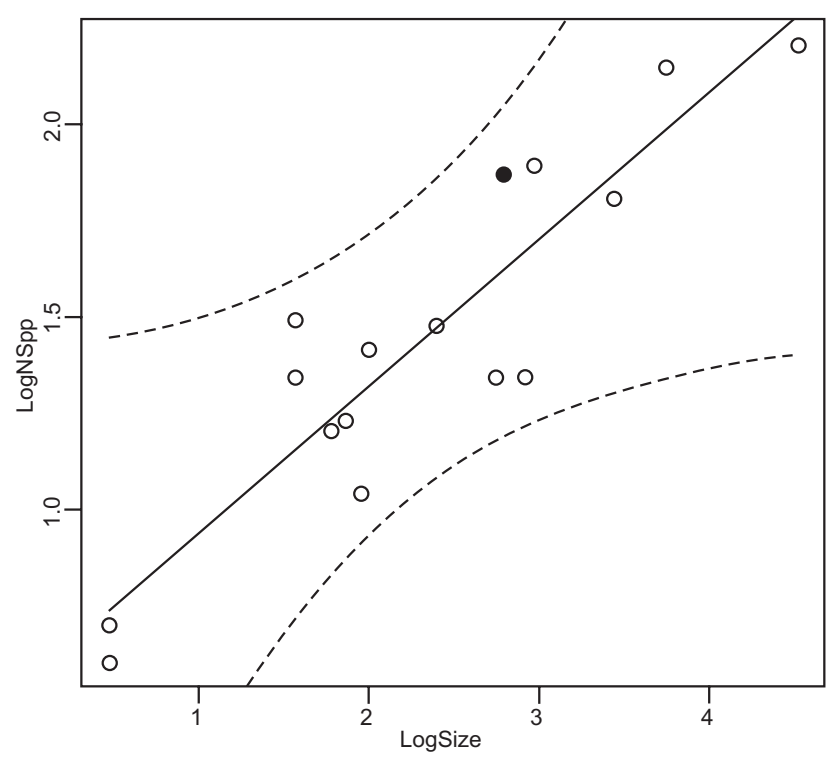

Figure 2. Regression curve of the species-area relationship (Logtransformed) of the bird richness and island size in offshore islands in the coast of Brazil. Dot lines are confidence intervals and the black dot is the Anchieta Island.

Table I. Bird species richness and island size on the inshore islands in the Atlantic rain forest, Brazil.

\begin{tabular}{|c|c|c|c|}
\hline Site & Size (ha) & $\begin{array}{c}\text { Number forest } \\
\text { dwelling species }\end{array}$ & Reference \\
\hline Costa, RJ & 3 & 4 & 1 \\
\hline Pombas, RJ & 3 & 5 & 1 \\
\hline Pombeba, RJ & 3 & 5 & 1 \\
\hline Galhetas, PR & 37 & 31 & 2 \\
\hline Palmas, PR & 37 & 22 & 2 \\
\hline Convivência, RJ & 60 & 16 & 1 \\
\hline Currais, PR & 73 & 17 & 2 \\
\hline Jorge, RJ & 90 & 11 & 1 \\
\hline Santana, RJ & 100 & 26 & 1 \\
\hline Jaguanum, RJ & 250 & 30 & 1 \\
\hline Cabo Frio, RJ & 560 & 22 & 1 \\
\hline Anchieta, SP & 826 & 73 & This study \\
\hline Itacuruça, RJ & 830 & 22 & 1 \\
\hline Cotinga, PR & 937 & 78 & 2 \\
\hline Mel, PR & 2,762 & 64 & 2 \\
\hline Grande, RJ & 5,600 & 140 & 1 \\
\hline Ilhabela, SP & 33,356 & 160 & 3 \\
\hline
\end{tabular}

1) Coelho et al. (1991), 2) Moraes (Unicamp, unpub. data),

3) OLmos (1996). 
in Anchieta Island (Tab. II). Therefore, bird species in Anchieta Island is a random subset of Caraguatatuba for most guilds (Tab. II), but there was a large non-random increase of the opportunist omnivore/insectivores guild.

Extinctions were not completely random across different nesting habitats (Tab. III). There was an over-representation of bird species that nest in aerial closed sites in Anchieta Island, while there were no resident bird species that nest on the ground-opened, and only nine species (six residents and three vagrants) that nests into trunk cavities on Anchieta (Tab. III). Differently, three nesting strategies: aerial opened, ground closed, and nest parasites are small, random subsets of birds in the mainland (Tab. III).

Table III. Bird species grouped by their nest habitats on the mainland of Serra do Mar (Caraguatatuba) and Anchieta Island. The actual number of species in Anchieta is the sum of two numbers, respectively, the number of species that also occurs in Caraguatatuba $(\mathrm{N}=60)$ and the number of species that only occur in Anchieta $(\mathrm{N}=7)$. The expected number of species is the mean predicted by our null model (see text for further details). ${ }^{*} p<0.05$.

\begin{tabular}{lrlc}
\hline \multirow{2}{*}{ Nest type } & \multicolumn{2}{c}{ Site } & \begin{tabular}{c} 
Expected number of \\
\cline { 2 - 4 }
\end{tabular} \\
\cline { 2 - 4 } Mainland & Anchieta & Species for Anchieta Island \\
\hline Aerial-open & 115 & $42+6$ & 34.71 \\
Aerial-closed & 23 & 10 & $6.95^{*}$ \\
Cavity & 45 & $8+1$ & $13.52^{*}$ \\
Nest parasites & 2 & 0 & 0.55 \\
Ground-opened & 10 & 2 & $3.04^{*}$ \\
Ground-closed & 4 & 0 & 1.17 \\
\hline
\end{tabular}

The frequency of resident and non-resident species differed significantly between Anchieta Island and the mainland $\left(\chi^{2}=5,48\right.$, df $\left.1, p=0,019\right)$. About $27 \%$ of all bird species at Anchieta were non-resident, i.e. they do not breed on the island, and include a few migrants (13 species). Twenty-six species were vagrant, which means that they were observed only once at the island, while another $23(22,77 \%)$ were rare, or with very few individuals in Anchieta (Appendix I).

\section{Nest predation}

The frequency of nest predation on the ground was higher than in the understory (73.33 vs $27 \% ; \chi^{2}=14.076$, df $=1$, p < $0.001)$ at Anchieta, but not on the mainland (33\% and 27\%; $\left.\chi^{2}=0.317, \mathrm{df}=1, \mathrm{p}=0.573\right)$. Nest predation on the ground differed between the island and the mainland $\left(\chi^{2}=0.9 .64\right.$, $\mathrm{df}=1, \mathrm{p}=0.0019$ ), but not in the understory.

Camera traps recorded three species of nest predators for ground and aerial nests. Opossums (Didelphis aurita, Wied, 1826) were the most common nest predators on the island (10 photos), followed by agoutis (Dasyprocta leoprina, Linnaeus, 1758,
17 photos), coatis (Nasua nasua, Linnaeus, 1766, 10 photos), and tegu lizard (Tupinambis merianae, Linnaeus, 1758, one photo). At the mainland we recorded only the opossum (10 photos). In addition, a group of marmosets was seen preying on a juvenile of the Sayaca tanager (Thraupis sayaca, Linnaeus, 1766, Emberezidae) at Anchieta Island, showing that not only eggs or nestlings are vulnerable to predation.

\section{DISCUSSION}

This study shows that although the number of bird species found on Anchieta is within the predicted species richness based on a species-area relationship, some nest guilds such as ground-closed and nest parasites are absent on this island. Poaching, deforestation and the recent introduction of mesopredators are probably the major drivers of the modification to the bird community. Mesopredators may be influencing the bird composition by preying on select species and by inhibiting colonization from the mainland. Anchieta Island has twice the primate density, five times more mesopredators and four times more agoutis than several large well protected Atlantic forests on the mainland (Bovendorp \& GaletTI 2007).

In the past 100 years, half of the island was cleared for the prison construction, while the elevated herbivory caused by domestic pigs, goats, capybaras and agoutis, left the vegetation highly disturbed (Alvarez et al. 2008). This intense land use transformed the island vegetation into a secondary forest mixed with exotic and invasive species with poor fruit productivity (Genini et al. 2009). Only 550 ha (c. 66\%) of the island is covered by secondary forest and $44 \%$ by the fern Gleichenium sp. and exposed soils (M. Fleury, Universidade de São Paulo, unpublished data). Therefore, forest specialists, such as the toucanets (Selenidera maculirostris, Lichteinstein, 1823, and Pteroglosus bailloni, Vieillot, 1819), the Blue-bellied parrot (Triclaria malachitacea, Spix, 1824), the Ferrugineous Antbird (Drymophilla ferruginea, Temminck, 1822) and the Rufousbreasted Leafscraper (Sclerurus scansor, Ménétriès, 1835), still common in the mainland, are lacking at Anchieta Island.

The bird fauna of Anchieta Island appears severely reduced when compared to adjacent mainland and forest fragments (Goerck 1997, Ribon et al. 2003, Faria et al. 2006), but it is in accordance to what has been found for other land-bridge islands in the Atlantic forest. The species abundances patterns may be quite different from the mainland because the community is dominated by a few hyperabundant species (Røv 1975,Wiens 1989). For instance, the density of Turdus albicollis (Seebohm, 1887) (Turdidae) is 12 times higher and Turdus flavipes (Vieillot, 1818) four times higher on Anchieta than on the mainland Serra do Mar (FADini et al. 2009).

The relationship between island size and number of forest-dependent bird species in the land-bridge islands along the coast of the Atlantic rain forest is extremely hard to predict by the well-known models of island biogeography (MACARTHUR \& WiLlson 1967), because (1) there are few surveys of birds on 
most of the islands (see COELHo et al. 1991, NAKA et al. 2002, MARSDEn et al. 2003), (2) many bird species were probably extinct before ornithologists became aware (see NAKA et al. 2002). Therefore, our estimate on bird species richness from Anchieta Island is probably an underestimation of the diversity that was present before European colonization.

Many well know bird species that are expected to be found at Anchieta are lacking. For instance, the lack of game species is most evident and is probably due to heavy hunting regime in the past. Guans, as well as large other large-bodied species, are present in smaller and isolated forest fragments on the mainland. Additionally, tinamids and guans are known to crossing large open water gaps and they could cross the $400 \mathrm{~m}$ of sea gap between the mainland and the island. Both groups of species, represented by at least five species, are present in the mainland (R. S. Bovendorp, Universidade de São Paulo, pers. comm.).

Large frugivores that require large areas to survive (Willis 1979, GoERCK 1997) such as toucans, and large psittacids, also do not occur on the island. We recorded just two species of large cotingas on Anchieta (Procnias nudicollis (Vieillot, 1817) and Pyroderus scutatus (Shaw, 1792), but they are infrequent visitors (FADINI et al. 2009). Forest eagles as well as falcons and birds or prey are extremely rare. Bamboo specialists, such as antbirds and ovenbirds (Rodrigues et al. 1994), large terrestrial ant-thrushes and even gnat-eaters are all absent at Anchieta. One of the most notable absences if the Speckle-breasted Antpitta (Hylopezus nattereri, Pinto, 1937), a large forest floor bird which occurred on the island just before mammal introduction (Guillaumon et al. 1989), but it was not recorded in our census. In this turn, we believe that most of these absences are a result of high rates of nest predation on Anchieta.

The patterns of nest predation observed in our study was similar to those recorded by LoIselle \& Hoppes (1983) in Barro Colorado Island (BCI), Panama: an elevated nest predation on the floor (88\%) and a lower predation of understory nests (11\%). It is important to notice that these authors did not record the same pattern in the mainland (LoIselLe \& Hoppes 1983). Terborgh et al. (1997) found that islands with high densities of capuchin monkeys had overwhelmingly high levels of nest predation in the Lago Guri, Venezuela.

Our empirical and simulation results support the notion that the extinction of some bird species, especially those that nest on the floor, may be related to nest predation by the elevated abundance of mesopredators (Wilcove 1985, GibBs 1991). In fact, the few natural nests that we found (e.g. Amazilia spp.) were preyed upon in a few days. Opossums and marmosets were spotted preying upon nestlings at Anchieta Island and our data with camera traps also recorded a high predation risk by coatis and opossums. Additionally, tegu lizards are also expected to predate most of the ground nests.

Nowadays, there are only two species of birds that could nest on the forest floor at Anchieta (nightjars), and there is strong evidence that ground-nesting birds have being wiped out from the island due intense nest predation. Ground-nesting birds occur even in highly disturbed small forest fragments, such as small tinamous (Crypturellus), quails, nightjars and several passerine birds (Aleixo \& Vielliard 1995, Willis 1979). The same pattern was found for cavity-nesting birds. Only nine species nest on cavities at Anchieta, including the Sharp-tailed Streamcreeper, a bank-nesting species. The remaining four species, including two piculets and two foliage-gleaners ovenbirds, nest in tree holes. Cavity-nesting birds, such as parrots and woodpeckers are common species in the nearest mainland. At least 16 (7\%) bird species in the mainland of Serra do Mar nests on the forest floor and another 37 (18\%) in tree holes.

\section{The surviving bird community at Anchieta Island}

One of the main distinctions of the avifauna of Anchieta Island is between water crossing and non-water crossing species (DiAmond 1984). From the 73 forest dwelling bird species recorded at Anchieta Island, 90\% are known to cross open areas between fragments or sea gaps (Olmos 1996, BierregaArd \& Stouffer 1997, Sick 1997). Hence, no-water crossing species that once occurred at Anchieta and became locally extinct may have serious problems in re-colonizing the island.

Most bird guilds were affected negatively at Anchieta Island, but the opportunist omnivore/insectivore edge insectivore guild was positively affected. Some guilds were severely affected. For instance, only one ant-bird species thrives at Anchieta Island (Dysithamnus mentalis, Themminck, 1823) and according to the "limited dispersal hypothesis" (see SEKERCioglu et al. 2002), understory insectivores face local extinction in isolated fragmented forests, because of their relatively sedentary habits and possible behavioral avoidance of clearings (Willis 1979, BierregaArd \& Stouffer 1997, Sekercioglu et al. 2002). The sea gap between the mainland and Anchieta Island might be a great barrier for this guild. However, it is notable that even isolated small forest fragments have more species of understory insectivores than Anchieta Island (Aleixo \& Vielliard 1995).

Another missing family at Anchieta Island is the Psittacidae. Parakeets and parrots are extremely common in the mainland, even in small forest fragments (Aleixo \& Vielliard 1995). Psitacids are good flyers and they can easily cross the sea gap that divides Anchieta Island from the mainland. Surprisingly, the only species recorded at Anchieta was a group of vagrant Parrotlet Forpus xanthopterigius (Spix, 1824), which was recorded only once. At least for parrots, the distance to the mainland is not a barrier for colonization of Anchieta.

The pattern of bird extinction found at Anchieta may also occur in many islands in the coast of the Neotropics. Most islands suffer from species introduction and forest reduction, both of which can have a significant impact on bird communities. The bird community at Anchieta Island cannot be restored if the current high densities of nest predators and herbivores are maintained. The most effective response to restore the bird community is to control the mammalian population, either by regularly reducing their numbers, or better still, by 
eradicating the population of some species as a whole from the island. As a first step, we suggest the complete eradication of marmosets because it is the only "truly" exotic species, since Callithrix penicillata (É. Geoffroy, 1812) does not occur in the coastal Atlantic forest.

In addition, we must increase the carrying capacity of the vegetation, especially through the restoration of young secondary forest or open areas. Nowadays, Anchieta Island has one of the smallest fruit productivity in the Atlantic forest (GeNINI et al. 2009) and the tree community is dominated by few species (V.B. Zipparro, Universidade Estadual Paulista, unpublished data). Some important families for fruit-eating birds are lacking or have being severely reduced, such as Lauraceae, Myrtaceae, and Myristicaceae (V.B. Zipparro, Universidade Estadual Paulista, unpublished data). Due to the high density of mammalian seed predators or herbivores, such as agoutis and capybaras, the restoration of vegetation will only succeed if we control their populations in the island (Alvarez et al. 2008, FADINI et al. 2009).

All islands in the Atlantic coastal forest of Brazil have suffered from intense human pressure, where native vegetation has been highly disturbed and exotic species have been introduced (e.g. Olmos 1996, 2005, NAKA et al. 2002). These "ecological paradises", highly publicized by the media are, in fact, product of chronic biological impoverishment caused by humans and the species introduced by them. Nevertheless, landbridge islands, such as Anchieta Island, may have an important role in bird conservation in the future, since some of them are more easily protected (especially from poaching) than areas in the mainland. Once these mesopredators are controlled or become eradicated, and the forest restored to its primitive levels, some bird species will have to be reintroduced in the island because of their poor ability to cross open areas.

At the moment, Anchieta Island is probably operating as a sink area from water-crossing bird species due to the high density of nest predators incorrectly introduced by humans.

\section{ACKNOWLEDGEMENTS}

We would like to thank FAPESP (Project Biota 2001/144635) for financial support. MR Laboratory of Ornithology is supported by Fundação O Boticário de Proteção à Natureza and CNPq (473428/2004-0). To Instituto Florestal for permission to work at Anchieta Island. We are especially indebted to Maria Robim and Manoel Fontes for their constant support to our studies in Anchieta. We also thank R.M. Marques, A. Fernandes, C. Faria, L. Atzeni, J. Genini and R. Bueno for invaluable help during the field work. C. Jenkins, A. Valido and two anonymous reviewers for helpful comments on the manuscript. MG, MR, RB and RF received a fellowship from $\mathrm{CNPq}$, and PG from FAPESP.

\section{LITERATURE CITED}

Aleixo, A. \& J. M. E. Vielliard. 1995. Composition and dynamics of the bird community of mata de Santa Genebra, Campinas, São Paulo, Brazil. Revista Brasileira de Zoologia 12: 493-511.
Alvarez, A.D.; R.S. BovendorP; M. Fleury \& M. Galettr. 2008. Paraísos de exóticos. Ciência Hoje 41: 69-71.

Alvarez, A. \& M. Galetti. 2007. Predação de ninhos artificiais em uma ilha na Mata Atlântica: testando o local e o tipo de ovo. Revista Brasileira de Zoologia 24: 1011-1016.

Anjos, L. \& R. Boçon. 1999. Bird communities in natural forest patches in southern Brazil. Wilson Bulletin 111: 397-414.

Bıвву, C.J. 1995. Recent past and future extinctions in birds, p. 98-110. In: J. H. LAWTON \& R. M. MAY (Eds). Extinction rates. Oxford, Oxford University Press, 248p.

BierregaArd, R.O. \& P.C. Stouffer. 1997. Understory birds and dynamic habitat mosaics in Amazonian Rainforests, p. 138155. In: W.F. Laurance \& R.O. BierregaARd JR (Eds). Tropical forest remnants: ecology, management, and conservation of fragmented communities. Chicago, University of Chicago Press, 632p.

Blackburn, T.M.; P. Cassey; R.P. Duncan; K.L. Evans \& K.J. Gaston. 2004. Avian extinction and mammalian introductions on oceanic islands. Science 305: 1955-1958.

Bovendorp, R. \& \& M. Galetti. 2007. Density and population size of mammals introduced on a land-bridge island in southeastern Brazil. Biological Invasions 9: 353-357.

Bovendore, R.S.; A.D. Alvarez \& M. GaletTi. 2008. Density of the tegu lizard (Tupinambis merianae) and its role as nest predator at Anchieta island, Brazil. Neotropical Biology and Conservation 3: 9-12.

Burke, D.M.; K. Eliliott; L. Moore; W. Dunford; E. Nol; J. Phillips; S. Holmes \& K. Freemark. 2004. Patterns of nest predation on artificial and natural nests in forests. Conservation Biology 18: 381-388.

Clout, M.N. 2002. Biodiversity loss caused by invasive alien vertebrates. Zeitschrift Fur Jagdwissenschaft 48: 51-58.

Coelho, E.P.; V.S. Alves; F.A.S. Fernandez \& M.L.L. Soneghet. 1991. On the bird faunas of coastal islands of Rio de Janeiro state, Brazil. Ararajuba 2: 31-40.

Courchamp, F.; J. L. Chapuis \& M. Pascal. 2003. Mammal invaders on islands: impact, control and control impact. Biological Reviews 78: 347-383.

Cuthbert, R. \& G. Hilton. 2004. Introduced house mice Mus musculus: a significant predator of threatened and endemic birds on Gough Island, South Atlantic Ocean? Biological Conservation 117: 483-489.

Diamond, J. M. 1984. Distributions of New Zealand birds on real and virtual islands. New Zealand. New Zealand Journal of Ecology 7: 37-55.

Emmel, C. T. 1976. Population Biology. London, Chapman \& Hall, 246p.

Fadini, R.F.; M. Fleury; C.I. Donatti \& M. GaletTi. 2009. Effects of frugivore impoverishment and seed predators on the recruitment of a keystone palm. Acta Oecologica 35: 188196.

Faria, C.M.A.; M. Rodrigues; F.Q. Amaral; E. Modena \& A.M. Fernandes. 2006. Aves de um fragmento de Mata Atlântica 
no alto rio Doce, Minas Gerais: Colonização e extinção. Revista Brasileira de Zoologia 23: 1217-1230.

Genini, J.; Galetti, M. \& L.P.C. Morellato. 2009. Fruiting phenology of palms and trees in an Atlantic rainforest land-bridge island. Flora 204: 131-145.

GibBS, J.P. 1991. Avian nest predation in tropical wet forest: an experimental study. Oikos 60: 155-161.

Goerck, J.M. 1997. Patterns of rarity in the birds of the Atlantic Forest of Brazil. Conservation Biology 11: 112-118.

Gotelli, N. \& G.R. Graves. 1996. Null models in ecology. Washington, Smithsonian Institution Press, 368p.

Guillaumon, J.R.; M.A.P. Marcondes; O.C. Negreiros; I.S. Mota; W. Emmerich; A.F. Barbosa; I.H.D.C. Branco; J.J.C. Camara; S. Ostini; R.T.L. Pereira; J.D. Scorvo-Filho; P.Y. Shimomichi; D.A. Silva \& J.E. Melo Neto. 1989. Plano de Manejo do Parque Estadual da Ilha Anchieta. São Paulo, Secretaria do Meio Ambiente do Estado de São Paulo, 215p.

Loiselle, B.A. \& W.G. Hoppes. 1983. Nest predation in insular e mailand lowland rainforest in Panama. Condor 85: 93-95.

MacArthur R. H. \& E. O. Wilson. 1967. The theory of island biogeography. Princeton, Princeton University Press, 224p.

Maier, T. J. \& R. M. DeGraaf. 2000. Predation on Japanese Quail vs. House Sparrow eggs in artificial nests: Small eggs reveal small predators. Condor 102: 325-332.

Manly, B. J. F. 1997. Randomization, bootstrap and Monte Carlo methods in biology. London, Chapman \& Hall, 480p.

Marsden, S.; J.M. Whiffin; L. Sadgrove \& P.R. Guimarães Jr. 2003. Bird Community composition and species abundance on two inshore islands in the Atlantic Forest region of Brazil. Ararajuba 11: 181-187.

Myers, N.; R.A. Mittermeier; C.G. Mittermeier; G.A.B. Fonseca \& J. KENT. 2000. Biodiversity hotspots for conservation priorities. Nature 403: 853-858.

NakA, L.N.; M. Rodrigues; A.L. Roos \& M.A.G. Azevedo. 2002. Bird conservation on Santa Catarina Island, Southern Brazil. Bird Conservation International 12: 123-150.

Nogales, M.; A. Martin; B.R. Tershy; C.J. Donlan; D. Witch; N. Puerta; B. Wood \& J. Alonso. 2004. A review of feral cat eradication on islands. Conservation Biology 18: 310-319.

Olmos, F. 1996. Missing species in São Sebatião Island, Southeastern Brazil. Papéis Avulsos de Zoologia 39: 329-349.

Olmos, F. 2005. Aves ameaçadas, prioridades e políticas de conservação no Brasil. Natureza \& Conservação 3: 21-42.

Ribon, R.; J.E. Simon \& G.T. Mattos. 2003. Bird extinctions in Atlantic forest fragments of the Viçosa region, southeastern Brazil. Conservation Biology 17: 1827-1839.

Robinet, O.; J.L. Craig \& L. Chardonnet. 1998. Impact of rat species in Ouvea and Lifou (Loyalty Islands) and their consequences for conserving the endangered Ouvea Parakeet. Biological
Conservation 86: 223-232.

Rodrigues, M.; S.M.R. Alvares \& C.G. Machado. 1994. Foraging behavior of the white-collared foliage gleaner (Anabazenops fuscus), a bamboo specialist. Ornitologia Neotropical 5: 65-67.

Røv, N. 1975. Breeding bird community structure and species diversity along an ecological gradient in deciduous Forest in western Norway. Ornis Scandinavica 6: 1-14.

Sekercioglu, C.H.; P.R. Ehlrich; G.C. Daily; D. Aygen; D. Goehring $\&$ R.F. SANDI. 2002. Disappearance of insectivorous birds from tropical forest fragments. Proceedings of the National Academy of Sciences of the United States of America 99: 263-267.

SICK, H. 1997. Ornitologia brasileira. Rio de Janeiro, Editora Nova Fronteira, $2^{\text {nd }}$ ed., 862 p.

Sieving, K.E.1992. Nest predation and differential insular extinction among selected forest birds of central panama. Ecology 73: 2310-2328.

Silva, J.M.C.; M. Souza \& C.H.M. Castelletti. 2004. Areas of endemism for passerine birds in the Atlantic forest, South America. Global Ecology and Biogeography 13: 85-92.

Stotz, D.F.; J.W. Fitzpatrick; T.A. Parker III \& D.K. Moskovits. 1996. Neotropical birds: ecology and conservation. Chicago, University of Chicago Press, 502p.

Terborgh, J.; L. Lopez; D. Yu \& A.R. Bruni. 1997. Transitory states in relaxing ecosystems of land bridge islands, p. 256-274. In: W.F. Laurance \& R.O. Bierregaard (Eds). Tropical forest remnants: ecology, management, and conservation of fragmented communities. Chicago, University of Chicago Press, 632p.

Terborgh, J.; L. Lopes; P. Nunez; M. Rao; G. Shahabuddin; G. Orihuela; M. Riveros; R. Ascanio; G.H. Adler; T.D. Lambert \& L. Balbas. 2001. Ecological meltdown in predator-free forest fragments. Science 294: 1923-1926.

Thibault, J.C.; J.L. Martin; A. Penloup \& J.Y. Meyer. 2002. Understanding the decline and extinction of monarchs (Aves) in Polynesian Islands. Biological Conservation 108: 161174.

VITOUSEK, P.M.; L.L. LOOPE \& H. AdSERSEN. 1995. Islands: biological diversity and ecosystem function. Berlin, Springer, 238p.

Wege, D.C. \& A.J. Long. 1995. Key areas for threatened birds in the Neotropics. Cambridge, BirdLife International, 311p.

WiENS, J.A. 1989. The ecology of bird communities: foundations and patterns. Cambridge, Cambridge University Press, 539 p.

Wilcove, D.S. 1985. Nest predation in forest tracts and the decline of migratory songbirds. Ecology 66: 1211-1214.

Willis, E.O. 1979. The composition of avian communities in remanescent woodlots in southern Brazil. Papéis Avulsos de Zoologia 33: 1-25. 
Appendix I. Bird list of Anchieta Island, Ubatuba, São Paulo, Brazil.

\begin{tabular}{|c|c|c|c|c|}
\hline Family/species & Habitat & Guild & Status & Relative abundance \\
\hline \multicolumn{5}{|l|}{ Sulidae } \\
\hline Sula leucogaster (Boddaert, 1783) & s & c & Non-resident & $\mathrm{v}$ \\
\hline \multicolumn{5}{|l|}{ Phalacrocoracidae } \\
\hline Phalacrocorax brasilianus (Gmelin, 1789) & s & c & Non-resident & $v$ \\
\hline \multicolumn{5}{|l|}{ Fregatidae } \\
\hline Fregata magnificens (Mathews, 1914) & s & c & Resident & c \\
\hline \multicolumn{5}{|l|}{ Ardeidae } \\
\hline Nyctanassa violacea (Linnaeus, 1758) & $r$ & c & Resident & $r$ \\
\hline Egretta thula (Molina, 1782) & $r$ & c & Resident & c \\
\hline \multicolumn{5}{|l|}{ Cathartidae } \\
\hline Cathartes aura (Linnaeus, 1758) & $\mathrm{f}, \mathrm{o}$ & c & Resident & c \\
\hline Coragyps atratus (Bechstein, 1793) & $f, o$ & c & Resident & c \\
\hline \multicolumn{5}{|l|}{ Accipitridae } \\
\hline Accipiter striatus (Vieillot, 1818) & $f$ & c & Resident & r \\
\hline Rupornis magnirostris (Gmenlin, 1788) & $\mathrm{f}, \mathrm{o}$ & c & Resident & c \\
\hline Buteo brachyurus (Vieillot, 1816) & $f$ & c & Non-resident & v \\
\hline \multicolumn{5}{|l|}{ Falconidae } \\
\hline Caracara plancus (Miller, 1777) & $\mathrm{e}, \mathrm{o}$ & c & Resident & c \\
\hline Milvago chimachima (Vieillot, 1816) & e, o & c & Resident & c \\
\hline Falco femoralis (Temminck, 1822)) & $e, o$ & c & Non-resident & $v$ \\
\hline \multicolumn{5}{|l|}{ Rallidae } \\
\hline Aramides cajanea (Statius Muller, 1776) & $f$ & ooi & Resident & c \\
\hline Pardirallus nigricans (Vieillot, 1819) & r & ooi & Resident & r \\
\hline \multicolumn{5}{|l|}{ Charadriidae } \\
\hline Pluvialis squatarola (Linnaeus, 1758) & s & ooi & Non-resident & $v$ \\
\hline \multicolumn{5}{|l|}{ Laridae } \\
\hline Larus dominicanus (Lichtenstein, 1823) & s & c & Resident & c \\
\hline \multicolumn{5}{|l|}{ Sternidae } \\
\hline Sterna hirundinacea (Lesson, 1831) & s & c & Non-resident & $v$ \\
\hline \multicolumn{5}{|l|}{ Columbidae } \\
\hline Patagioenas cayennensis (Bonnaterre, 1792) & $\mathrm{e}, \mathrm{o}$ & af & & \\
\hline Patagioenas plumbea (Vieillot, 1818) & $f$ & af & Non-resident & $\mathrm{v}$ \\
\hline Leptotila verreauxi (Bonaparte, 1855) & $e, f$ & $\operatorname{tg}$ & Resident & c \\
\hline Leptotila rufaxilla (Richard \& Bernard, 1792) & $e, f$ & $\operatorname{tg}$ & Resident & c \\
\hline Geotrygon montana (Linnaeus, 1758) & $f$ & $\operatorname{tg}$ & Non-resident & $\mathrm{v}$ \\
\hline \multicolumn{5}{|l|}{ Psittacidae } \\
\hline Forpus xanthopterygius (Spix, 1824) & $e, f$ & af & Non-resident & v \\
\hline \multicolumn{5}{|l|}{ Cuculidae } \\
\hline Piaya cayana (Linnaeus, 1766) & $e, f$ & $\mathrm{ci}$ & Resident & r \\
\hline
\end{tabular}


Appendix I. Continued.

\begin{tabular}{|c|c|c|c|c|}
\hline Family/species & Habitat & Guild & Status & Relative abundance \\
\hline \multicolumn{5}{|l|}{ Caprimulgidae } \\
\hline Nyctidromus albicollis (Gmelin, 1789) & $o, f$ & ti, ooi & Non-resident & $\mathrm{v}$ \\
\hline Hydropsalis torquata (Gmelin, 1789) & $o, f$ & ti, ooi & Resident & $\mathrm{r}$ \\
\hline \multicolumn{5}{|l|}{ Apodidae } \\
\hline Streptoprocne zonaris (Shaw, 1796) & f, o & ai & Non-resident & $v$ \\
\hline Chaetura meridionalis (Hellmayr, 1907) & f, o & ai & Resident & $\mathrm{r}$ \\
\hline \multicolumn{5}{|l|}{ Trochilidae } \\
\hline Glaucis hirsutus (Gmelin, 1788) & $f$ & ni & Non-resident & $\mathrm{v}$ \\
\hline Phaethornis ruber (Linnaeus, 1758) & $f$ & ni & Resident & $\mathrm{r}$ \\
\hline Florisuga fusca (Vieillot, 1817) & $f$ & ni & Non-resident & $\mathrm{v}$ \\
\hline Thalurania glaucopis (Gmelin, 1788) & $f$ & ni & Resident & c \\
\hline Amazilia fimbriata (Gmelin, 1788) & $\mathrm{f}, \mathrm{o}$ & ni & Resident & c \\
\hline Alcedinidae & & & Resident & \\
\hline Megaceryle torquata (Linnaeus, 1766) & $o, r$ & c & Resident & c \\
\hline Chloroceryle americana (Gmelin, 1788) & $o, r$ & c & Resident & c \\
\hline \multicolumn{5}{|l|}{ Picidae } \\
\hline Picumnus cirratus (Temminck, 1825) & $f$ & $\mathrm{tti}$ & Resident & c \\
\hline Picumnus temminckii (Lafresnaye, 1845) & $f$ & tti & Resident & $\mathrm{r}$ \\
\hline Dryocopus lineatus (Linnaeus, 1766) & $f$ & tti & Non-resident & $v$ \\
\hline \multicolumn{5}{|l|}{ Thamnophilidae } \\
\hline Dysithamnus mentalis (Temminck, 1823) & $f$ & ui & Resident & c \\
\hline \multicolumn{5}{|l|}{ Dendrocolaptidae } \\
\hline Lepidocolaptes angustirostris (Vieillot, 1818) & o & tti & Non-resident & $v$ \\
\hline \multicolumn{5}{|l|}{ Furnariidae } \\
\hline Synallaxis ruficapilla (Vieillot, 1819) & $f$ & bi & Resident & $r$ \\
\hline Synallaxis spixi (Sclater, 1856) & $e, f$ & ui & Resident & c \\
\hline Philydor atricapillus (Wied, 1821) & $f$ & ui & Resident & c \\
\hline Automolus leucophthalmus (Wied, 1821) & $f$ & ui & Resident & c \\
\hline Lochmias nematura (Lichtenstein, 1823) & $f, r$ & ti & Resident & $\mathrm{r}$ \\
\hline \multicolumn{5}{|l|}{ Tyrannidae } \\
\hline Leptopogon amaurocephalus (Tschudi, 1846) & $f$ & ui & Resident & c \\
\hline Elaenia flavogaster (Thunberg, 1822) & $f, o$ & ooi & Resident & c \\
\hline Camptostoma obsoletum (Temminck, 1824) & $e, f, o$ & ui & Resident & c \\
\hline Tolmomyias sulphurescens (Spix, 1825) & $f$ & $\mathrm{ci}$ & Resident & c \\
\hline Platyrinchus mystaceus (Vieillot, 1818) & $f$ & ui & Resident & $\mathrm{r}$ \\
\hline Hirundinea ferruginea (Gmelin, 1788) & o & ai & Non-resident & $v$ \\
\hline Lathrotriccus euleri (Cabanis, 1868) & $f$ & ui & Resident & $\mathrm{r}$ \\
\hline Fluvicola nengeta (Linnaeus, 1766) & o & $\mathrm{ti}$ & Resident & c \\
\hline Myiozetetes similis (Spix, 1825) & $e, f, o$ & ooi & Resident & c \\
\hline
\end{tabular}


Appendix I. Continued.

\section{Appendix I. Continued.}

Tyrannidae (continued)

Pitangus sulphuratus (Linnaeus, 1766)

Myiodynastes maculates (Statius Muller, 1776)

Megarhynchus pitangua (Linnaeus, 1766)

Empidonomus varius (Vieillot, 1818)

Myiarchus swainsoni (Cabanis \& Heine, 1859)

Myiarchus ferox (Gmelin, 1789)

Attila rufus (Vieillot, 1819)

Pipridae

Chiroxiphia caudata (Shaw \& Nodder, 1793)

Manacus manacus (Linnaeus, 1766)

Tityridae

Pachyramphus polychopterus (Vieillot, 1818)

Vireonidae

Cyclarhis gujanensis (Gmelin, 1789)

Vireo olivaceus (Linnaeus, 1766)

Cotingidae

Procnias nudicollis (Vieillot, 1817)

Pyroderus scutatus (Shaw, 1792)

Hirundinidae

Progne tapera (Vieillot, 1817)

Pygochelidon cyanoleuca (Vieillot, 1817)

Stelgidopteryx ruficollis (Vieillot, 1817)

Troglodytidae

Troglodytes musculus (Naumann, 1823)

Turdidae

Turdus flavipes (Vieillot, 1818)

Turdus rufiventris (Vieillot, 1818)

Turdus leucomelas (Vieillot, 1818)

Turdus amaurochalinus (Cabanis, 1850)

Turdus albicollis (Vieillot, 1818)

Emberezidae

Parula pitiayumi (Vieillot, 1817)

Geothlypis aequinoctialis (Gmelin, 1789)

Basileuterus culicivorus (Deppe, 1830)

Coerebidae

Coereba flaveola (Linnaeus, 1758)

$e, f, o$
$f$
$e, f$
$e, f$
$o, e$
$e$
$f$

Habitat

Guild

Status

Relative abundance

$\begin{array}{lll}\text { ooi } & \text { Resident } & \text { c } \\ \text { ooi } & \text { Non-resident } & \text { v } \\ \text { ooi } & \text { Resident } & \text { c } \\ \text { ooi } & \text { Resident } & \text { r } \\ \text { ooi } & \text { Non-resident } & \text { v } \\ \text { ooi } & \text { Resident } & \text { c } \\ \text { ooi } & \text { Resident } & \text { c }\end{array}$

\section{f \\ $e, f$}

f

f

f

$f$

f

e, o

o

e, $f, o$

e, $f$

$e, f, o$

$\mathrm{f}$

e, $f, o$

$f, o$

$\mathrm{f}$

e, $f, o$ ufi

ooi

ooi

cfi

ooi

ooi

af

af

Non-resident

Non-resident

ai

ai

ai

Non-resident

Resident

Resident

ooi

Resident

Resident

Resident

Resident

Resident

Resident

Resident

ci

ooi

Resident

Resident

Resident

ni

Resident c

r

c

c

v

v

$\mathrm{v}$

(1)

v

c

$r$

c

r

c

c

$r$

c

C

C

c

c

Continue 
Appendix I. Continued.

\begin{tabular}{|c|c|c|c|c|}
\hline Family/Species & Habitat & Guild & Status & Relative abundance \\
\hline \multicolumn{5}{|l|}{ Thraupidae } \\
\hline Trichothraupis melanops (Vieillot, 1818) & $f$ & ufi & Resident & $c$ \\
\hline Habia rubica (Vieillot, 1817) & $f$ & ufi & Resident & c \\
\hline Tachyphonus coronatus (Vieillot, 1822) & $e, f$ & ooi & Resident & c \\
\hline Ramphocelus bresilius (Linnaeus, 1766) & $e, f$ & ooi & Resident & c \\
\hline Thraupis sayaca (Linnaeus, 1766) & $e, f, o$ & ooi & Resident & c \\
\hline Thraupis palmarum (Wied, 1823) & $\mathrm{e}, \mathrm{o}$ & ooi & Resident & c \\
\hline Tangara cyanocephala (Statius Muller, 1776) & $f$ & cfi & Resident & c \\
\hline Tangara cayana (Linnaeus, 1766) & $e, f, o$ & ooi & Resident & $\mathrm{r}$ \\
\hline Dacnis cayana (Linnaeus, 1766) & $e, f$ & ni & Resident & $\mathrm{r}$ \\
\hline Hemithraupis ruficapilla (Vieillot, 1818) & $f$ & cfi & Resident & r \\
\hline \multicolumn{5}{|l|}{ Emberezidae } \\
\hline Zonotrichia capensis (Statius Muller, 1776) & o & ooi & Resident & $c$ \\
\hline Haplospiza unicolor (Cabanis, 1851) & $f$ & bi & Non-resident & $v$ \\
\hline Volatinia jacarina (Linnaeus, 1766) & o & ooi & Resident & $r$ \\
\hline Sporophila caerulescens (Vieillot, 1823) & o & ooi & Resident & r \\
\hline Tiaris fuliginosus (Wied, 1830) & $f$ & bi & Non-resident & $v$ \\
\hline \multicolumn{5}{|l|}{ Cardinalidae } \\
\hline Saltator similis (d'Orbigny \& Lafresnaye, 1837) & $e, f$ & ooi & Resident & c \\
\hline \multicolumn{5}{|l|}{ Fringillidae } \\
\hline Euphonia chlorotica (Linnaeus, 1766) & $e, f, o$ & cfi & Resident & c \\
\hline Euphonia pectoralis (Latham, 1801) & $f$ & ufi & Non-resident & $r$ \\
\hline
\end{tabular}

Habitat: (e) edge, (f) forest, (o) open area, (r) river, (s) sea. Guild: abbreviations as in table II, (ai) aerial insectivore. Relative abundance: (c) common, (r) rare, (v) vagrant.

Submitted: 28.VIII.2008; Accepted: 15.VI.2009.

Editorial responsability: Paulo Inácio López de Prado 